\title{
FIRST RECORD OF THE INDIAN MEAL MOTH, Plodia interpunctella (HUBNER 1813) (Lepidoptera: Pyralidae) FOR BRAZIL NUT
}

\author{
PRIMEIRO REGISTRO DA TRAÇA-DAS-FARINHAS Plodia interpunctella (HUBNER \\ 1813) (Lepidoptera: Pyrallidae) EM CASTANHA-DO-BRASIL
}

\author{
Flávia Batista GOMES ${ }^{1}$; Cristiane KRUG ${ }^{2}$; Jackson Guimarães TAVARES ${ }^{3}$ \\ 1. Analista, Embrapa Amazônia Ocidental - CPAA, Manaus, AM, Brasil, flavia.b.gomes@embrapa.br; 2. Pesquisadora, Embrapa \\ Amazônia Ocidental - CPAA, Manaus, AM, Brasil; 3. Bolsista PIBIC, Embrapa Amazônia Ocidental - CPAA, Manaus, AM, \\ Brasil.
}

\begin{abstract}
This is the first record in Brazil of an infestation of the Indian meal moth, Plodia interpunctella (Hubner 1813), for Brazil nut. P. interpunctella, is a cosmopolitan microlepidoptera of the family Pyralidae, considered an important insect pest of many different stored products. The record was for Brazil nut stored in bags in Itacoatiara county, Amazonas state.
\end{abstract}

KEYWORDS: Bertholletia excels. Stored products. Insect pest.

The Brazil nut, Bertholletia excelsa Humboldt e Bonpland, is a tree with multiple uses, being one of the most valuable species growing in the Amazon. Its main product are the seeds from which it gets almonds, known worldwide as Brazil nut, sold both in the domestic market and internationally, especially Bolivia, the United States, China and the European Union. In Brazil, Acre, Amazonas and Pará are the main producing states. The production of Brazil nuts has an important role in the economy of many extractive communities of northern Brazil (BAYMA et al. 2014). Brazil nuts are mainly collected from trees growing in natural forests (ZUIDEMA; BOOT 2002), moreover, the Brazil nut has been planted in different forestry systems in the Amazon, making up agroforestry systems or homogeneous plantings to recuperate disturbed areas, to restore tree plantings and for commercial production (COSTA et al. 2009, FERREIRA et al. 2012).

Plodia interpunctella (HUBNER 1813) is a microlepidoptera of the family Pyralidae, subfamily Phycitinae, commonly known as the Indian meal moth (TRIPLEHORN; JOHNSON 2011). $P$. interpunctella is a cosmopolitan species and an important pest recorded from many diverse stored products (NA; RYOO 2000). According to Nansen e Phillipis (2003), is a very important economic pest of dried fruits and oil-rich foodstuffs, such as cereals, meals and chocolate bars. Mbata e Osuji (1983) recorded its occurrence in peanuts and Johnson et al. (1992) in almonds, pistachio and nuts. Platt et al. (1998) observed a heavy infestation in pet foods in supermarkets. Na e Ryoo (2000) observed the Indian meal moth in dehydrated vegetables, chives, onions, garlic, carrots, cabbage and pepper. Garlic in natura is also attacked by this pest according to Perez-Mendonza e Aguilera-Peña (2004). Barbosa et al. (2008) noted its presence in seeds of the brassica species, Crambe abyssinica. The wide variety of hosts attacked by $P$. interpunctella characterizes it as a polyphagous species.

In April 2013, P. interpunctella was recorded in Brazil nut in the Aruanã farm $\left(03^{\circ} 00^{\prime} 29^{\prime}\right.$ ' south e $58^{\circ} 49^{\prime} 53^{\prime \prime}$ ' west) in Itacoatiara County, Amazonas State. The nuts had been stored in jute bags since the 2013 harvest (April/ 2013) and were stacked in batches on pallets. In May 2014, out of a total of 47 stored bags, adults, larvae and pupae were found in 20 bags or $42 \%$ of the total (personal communication of Jhonatan Bruno Silva).

In May 2014, a $62 \mathrm{~kg}$ bag of Brazil nuts was carried to the Laboratory of Entomology in Embrapa Amazônia Ocidental (Manaus-AM) for study. The pupae were observed in cocoons fixed to the nut and inside the bag. The characteristic web produced by this species was also observed, forming web lumps with excrement and exuviae on the bags, nuts and also on the shelled seeds. Samples of nuts were removed from the lower third, middle and top of the bag, a total of $10 \%$ of the nuts was sampled and evaluated the percentage of nuts attacked by $P$. interpunctella. It was called attacked the nuts with damage and/or presence of larvae.

The adult moths collected for this record are characterized by approximately $2 / 3$ of the distal region of the forewings having a reddish bronze color, with a greyish basal region and a black transversal stripe separating these two areas. The wing span is around $20 \mathrm{~mm}$ with head scales appearing as a crest. The larvae have a brown 
cephalic capsule and are a milky-white color. The final instar is rose-colored and about $1.3 \mathrm{~mm}$ long. The pupa develops inside a silk cocoon with a brownish anterior part and an amber-colored inferior part, measuring around $8 \mathrm{~mm}$. The specie was identified by the taxonomist of micromoths Vitor Becker, using adult insects collected of the nuts bag.

An average $3.19 \%$ of the nuts had been attacked by $P$. interpunctella, $2.61 \%$ in the upper and middle thirds and $4.35 \%$ in the lower third.

The attacked nuts had damaged seeds with galleries made by larvae and the interiors of some had been totally consumed. Lumps of web were also seen inside the nuts with the numbers of different larval instars, varying from 1 to 7 larvae per nut.

Considering the economic importance of the Brazil nut for northern Brazil, the value of the product, the polyphagy shown by $P$. interpunctella and the fact that it is a severe pest, special attention should be given to the storage of Brazil nuts. It was not found any record $P$. interpunctella attacking stored products in the North, however we must be attentive to storage products that can to be potential hosts the moth, like corn, beans, cowpea and cassava flour, commonly products produced in the North of the Brazil, as well as to the presence of other pests. Thus, the early detection is required or even the implementation of preventive control.

\section{ACKNOWLEDGEMENTS}

To Aruanã farm for making the attacked Brazil nuts available together with associated information, to Roberval Monteiro Bezerra de Lima (Embrapa Amazônia Ocidental).

RESUMO: Este é o primeiro registro no Brasil da infestação da traça-das-farinhas, Plodia interpunctella (Hubner 1813), em castanha-do-brasil. Plodia interpunctella é um microlepidóptero pertencente à família Pyralidae, cosmopolita e considerado importante inseto-praga dos mais variados produtos armazenados. $\mathrm{O}$ registro foi realizado em castanhas armazenadas em sacarias no município de Itacoatiara, estado do Amazonas.

PALAVRAS-CHAVE: Bertholletia excelsa. Produtos armazenados. Inseto-praga.

\section{REFERÊNCIAS}

BARBOSA, R. V.; SOUZA, G. C.; SALES, J. F.; PEIXOTO, M. F.; OLIVEIRA, R. R. C.; RODRIGUES, E.; MORAES, R. S., ROCHA, G. C. Ocorrência da traça Plodia interpunctella (Hubner, 1813) (Lepidoptera Pyralidae) em sementes de crambre armazenadas no IF Goiano - campus Rio Verde. In: XXII Congresso Brasileiro de Entomologia, 2008, Uberlândia, MG. Available at: http://www.seb.org.br/eventos/cbe/xxiiicbe (accessed 30 de June de 2014).

BAYMA, M. M. A.; MALAVAZI, F. W.; SÁ, C. P.; FONSECA, F. L.; ANDRADE, E. P.; WADT, L. H. O. Aspectos da cadeia produtiva da castanha-do-brasil no estado do Acre, Brasil. Boletim do Museu Paraense Emílio Goeldi. Ciências Naturais, Belém, v. 9, p. 417-426, 2014.

COSTA, J. R.; CASTRO, A. B. C.; WANDELLI, E. V.; CORAL, S. C. T.; SOUZA, S. A. G. Aspectos silviculturais da castanha-do-Brasil (Bertholletia excelsa) em sistemas agroflorestais na Amazônia Central. Acta Amazonica, Manaus, v. 39, p. 843-850, 2009. http://dx.doi.org/10.1590/S0044-59672009000400013

FERREIRA, M. J.; GONÇALVES, J. F. C.; FERRAZ, J. B. S. Crescimento e eficiência do uso da água de plantas jovens de castanheira-da-amazônia em área degradada e submetidas à adubação. Ciência Florestal, Santa Maria, v. 22, p. 393-401, 2012. http://dx.doi.org/10.5902/198050985747

JOHNSON, J. A.; WOFFORD, P. L.; Whitehand, L. C. Effect of diet and temperature on development rates, survival, and reproduction of the indian meal moth (Lepidoptera: Pyralidae). Journal Economy of Entomology, Annapolis, v. 85, p. 561-566, 1992. http://dx.doi.org/10.1093/jee/85.2.561

MBATA, G. N. J.; OSUJI, F. N. C. Aspects of the biology of Plodia interpunctella (Hubner) (Lepidoptera: Pyralidae), a pest of stored groundnuts in Nigeria. Journal of Stored Products Research, Great Britain, v. 19, p. 141-151, 1983. http://dx.doi.org/10.1016/0022-474X(83)90046-2 
NA, J. H.; RYOO, M. I. The infuence of temperature on development of Plodia interpunctella (Lepidoptera: Pyralidae) on dried vegetable commodities. Journal of Stored Products Research, Great Britain, v. 36, p. 125-129, 2000. http://dx.doi.org/10.1016/S0022-474X(99)00039-9

NANSEN, C.; PHILLIPS, T. W. Ovipositional responses of the indian meal moth, Plodia interpunctella (Hubner) (Lepidoptera: Pyralidae) to oils. Annals of the Entomological Society of America, Annapolis, v. 96, p. 524-531, 2003. http://dx.doi.org/10.1603/0013-8746(2003)096[0524:OROTIM]2.0.CO;2

PEREZ-MENDONZA, J.; AGUILERA-PEÑA, M. Development, reproduction, and control of the indian meal moth, Plodia interpunctella (Hubner) (Lepidoptera: Pyralidae), in stored seed garlic in Mexico. Journal of Stored Products Research, Great Britain, v. 40, p. 409-421, 2004. http://dx.doi.org/10.1016/S0022474X(03)00045-6

PLATT, R. R.; CUPERUS, G. W., PAYTON, M. E., BONJOUR, E. L.; PINKSTON, K.N. 1998. Integrated pest management perceptions and practices and insect populations in grocery stores in south-central United States. Journal of Stored Products Research, Great Britain, v. 34, p. 1-10, 1998.

http://dx.doi.org/10.1016/S0022-474X(97)00036-2

TRIPLEHORN, C. A.; JOHNSON, N. F. Estudo dos insetos. 7nd ed. Cengage Learning, São Paulo, 2011. $816 \mathrm{p}$.

ZUIDEMA, P. A.; BOOT, R. G. A. Demography of the Brazil nut tree (Bertholletia excelsa) in the Bolivian Amazon: impact of seed extraction on recruitment and population dynamics. Journal of Tropical Ecology, Cambridge, v. 18, p. 1-31, 2002. http://dx.doi.org/10.1017/S0266467402002018 